\title{
Participative Management
}

Participative management is a live subject in librarianship. It has been discussed frequently in the pages of this journal, and many academic librarians are directly involved in committees and projects of all sorts, communicating, setting goals, evaluating themselves and their peers, raising standards and productivity. Participation has heightened awareness. In the process, aspirations have been raised for librarianship and for librarians. For these reasons, the draft proposal of the National Commission on Libraries and Information Science should spur widespread interest from the library community. The report's recommendation for streamlining the bibliographic apparatus, integrating a disparate collection of libraries and information centers into a national system is long overdue. Yet because their expectations have been raised, librarians will also want to know more than the document now tells them, and how they fit into the proposed scheme.

Ironically, the word "librarians" doesn't even appear in this 18 page proposal called "A New National Program of Library and Information Service." True, the document does devote two brief paragraphs and a stray sentence or two to human resources. But the gist of these references is simply that human resource needs have not been assessed and that nobody knows just what they are (p. 3); and that new educational approaches to manpower development will be required (p. 11). Although this may imply that the proposed system will come to grips with the very real probability of technological unemployment, this matter remains ill-defined. And because technology is a sweeping current which may be redirected but cannot be reversed, this is only one aspect of a more overriding question. This concerns decision-making power and the nature and effects of library/information science work.

What role will the cataloger, administrator, reference librarian, academic librarian/specialist, etc. (or their future counterparts) have in the proposed national system of library and information centers? Will they participate in such decisions as what kinds of data bases or information and abstracting services will be included; how information will be analyzed; whom it will serve, and how the costs will be distributed when the system is operational? Will there be any assurances that critical viewpoints will be represented; that searches won't be made on who's requesting what data; that government information will be more accessible rather than less so as a result of the new system?

The Commission may have considered some of these questions, and its support for studies of user needs reflects an essential perspective. At the same time, the draft document itself is based on economic arguments, with a few social benefits thrown in. Persuasive as these may be, the document ignores any discussion of social costs.

In other areas of our existence, we have learned at our peril that these socalled "externalities" cannot be ignored. Least of all can we afford to ignore them in the knowledge industry. The NCLIS should examine how the recommended national library and information system will affect the knowledge workers who will operate it, and whether its social benefits to society will outweigh its social costs.

ANITA R. Schiller 